\title{
Role in virulence and protective efficacy in pigs of Salmonella enterica serovar Typhimurium secreted components identified by signature-tagged mutagenesis \\ Correspondence \\ Mark P. Stevens \\ mark-p.stevens@bbsrc.ac.uk \\ Received 15 January 2007 \\ Revised 7 February 2007 \\ Accepted 14 February 2007 \author{
Timothy S. Wallis ${ }^{1} \dagger$ and Mark P. Stevens ${ }^{1}$ \\ ${ }^{1}$ Division of Microbiology, Institute for Animal Health, Compton, Berkshire RG20 7NN, UK \\ ${ }^{2}$ Department of Veterinary Medicine, University of Cambridge, Madingley Road, Cambridge
} \\ Sonya C. Carnell, ${ }^{1}$ Alison Bowen, ${ }^{1}$ Eirwen Morgan, ${ }^{1}$ Duncan J. Maskell, ${ }^{2}$ CB3 OES, UK

\begin{abstract}
Salmonella enterica serovar Typhimurium ( $S$. Typhimurium) is a zoonotic enteric pathogen of worldwide importance and pigs are a significant reservoir of human infection. Signature-tagged transposon mutagenesis (STM) was used to identify genes required by $S$. Typhimurium to colonize porcine intestines. A library of 1045 signature-tagged mutants of S. Typhimurium ST4/74 $\mathrm{Nal}^{\mathrm{R}}$ was screened following oral inoculation of pigs in duplicate. A total of 119 attenuating mutations were identified in 95 different genes, many of which encode known or putative secreted or surface-anchored molecules. A large number of attenuating mutations were located within Salmonella pathogenicity islands (SPI)-1 and -2 , confirming important roles for type III secretion systems (T3SS)-1 and -2 in intestinal colonization of pigs. Roles for genes encoded in other pathogenicity islands and islets, including the SPI-6-encoded Saf atypical fimbriae, were also identified. Given the role of secreted factors and the protection conferred against other pathogens by vaccination with extracellular and type III secreted proteins, the efficacy of a secreted protein vaccine from wild-type $S$. Typhimurium following intramuscular vaccination of pigs was evaluated. Serum IgG responses against type III secreted proteins were induced following vaccination and a significant reduction in faecal excretion of $S$. Typhimurium was observed in the acute phase of infection compared to mock-vaccinated animals. Vaccination with secreted proteins from an isogenic $S$. Typhimurium prgH mutant produced comparable levels of protection to vaccination with the preparation from the parent strain, indicating that protection was not reliant on T3SS-1 secreted proteins. The data provide valuable information for the control of Salmonella in pigs.
\end{abstract}

\section{INTRODUCTION}

Salmonella enterica is an important zoonotic pathogen with the ability to infect a wide range of animal hosts. Infections can range in severity from subclinical infection, through mild diarrhoea, to severe systemic disease. In foodproducing animals such as pigs, calves and chickens $S$. enterica is a major cause of disease. Infections in pigs are predominantly associated with serovars Choleraesuis and Typhimurium. S. enterica serovar Choleraesuis ( $S$. Choleraesuis) causes a systemic, sometimes fatal, infection while $S$. Typhimurium causes a self-limiting enterocolitis but is rarely associated with mortality. A characteristic of

†Present address: Ridgeway Biologicals Ltd, c/o Institute for Animal Health, Compton, Newbury RG20 7NN, UK.

Abbreviations: Amp, ampicillin; Km, kanamycin; Nal, nalidixic acid; STM, signature-tagged mutagenesis; SPI, Salmonella pathogenicity island; T3SS, type III secretion system. serovar Typhimurium infection of pigs, however, is its ability to produce persistent and asymptomatic infections. Pigs with persistent infections can harbour and shed $S$. Typhimurium in their faeces for several months postexposure (Berends et al., 1996). These carriers and shedders can contaminate the food chain and environment via meat and faeces and represent a significant reservoir of human Salmonella infection (Hurd et al., 2002). In a year-long randomized UK national abattoir survey, $S$. Typhimurium was detected in the caeca of $11.1 \%$ of pigs presented for slaughter and on $2.1 \%$ of carcass swabs (Davies et al., 2004). Although serovar Typhimurium is the principal serovar isolated from UK pig herds our understanding of the pathogenesis of $S$. Typhimurium infections in swine is limited as relatively few studies have been carried out using pigs as an experimental model.

Recent studies have established that the Salmonella pathogenicity island (SPI)-1-encoded type III secretion 
system (T3SS-1) plays a pivotal role in intestinal, but not tonsillar, colonization in pigs (Boyen et al., 2006b), as well as in invasion of porcine pulmonary alveolar macrophages (Boyen et al., 2006a). Type I fimbriae have also been implicated in intestinal colonization of swine by serovar Typhimurium (Althouse et al., 2003). Most in vivo pig studies have focused on serovar Choleraesuis. Experimental studies using this serovar have indicated a role for the SPI1 transcriptional regulator hilA in enteric infection in pigs and, more recently, screening of random $S$. Choleraesuis mutants identified a number of SPI-1 and SPI-2 genes essential for systemic infection of pigs ( $\mathrm{Ku}$ et al., 2005; Lichtensteiger \& Vimr, 2003).

Working towards the aims of enhancing the health and welfare of farmed pigs and improving food safety, we have used signature-tagged mutagenesis (STM; Hensel et al., 1995) as a rapid high-throughput screen for $S$. Typhimurium factors that may be suitable for inclusion in vaccines. STM permits the simultaneous analysis of up to 95 uniquely tagged transposon insertion mutants for defects in virulence and has been used as a prelude to the testing of vaccines against a variety of bacterial pathogens (Collins et al., 2005; Flashner et al., 2004; Ku et al., 2005). This method has revealed that Salmonella uses both conserved and host-specific colonization factors in calves, chickens and mice (Bispham et al., 2001; Hensel et al., 1995; Morgan et al., 2004; Shah et al., 2005; Tsolis et al., 1999). Increasing awareness that Salmonella requires different genes in different hosts reinforces the need to extend these studies to a porcine model of infection.

Screening of the same serovar Typhimurium mutant library as recently characterized in calves and chickens (Morgan et al., 2004) identified 95 genes required for intestinal colonization of pigs. The data from this comprehensive survey indicate that secreted and surfaceanchored molecules, including fimbriae and type III secreted proteins, play pivotal roles in the carriage of $S$. Typhimurium in pigs. Vaccines based on extracellular factors and type III secreted proteins have shown protection against other bacterial pathogens, including Yersinia pestis in mice and enterohaemorrhagic Escherichia coli in cattle (Leary et al., 1995; Potter et al., 2004). We therefore exploited insights from STM to evaluate the efficacy of a $S$. Typhimurium secreted protein vaccine and probed the role of T3SS-1-secreted proteins in the protection observed.

\section{METHODS}

Bacterial strains and culture conditions. A nalidixic acid resistant mutant of Salmonella Typhimurium ST4/74 (a progenitor of SL1344; ST4/74 $\mathrm{Nal}^{\mathrm{R}}$ ) and a prgH : : mini-Tn5Km2 mutant of ST4/74 Nal${ }^{\mathrm{R}}$ were used in this study (Morgan et al., 2004). Both strains exhibited wild-type growth characteristics. Escherichia coli strain TOP10F' (Invitrogen) was used for subcloning of transposon-containing fragments in plasmid pBluescript $\mathrm{KS}(+)$ (Short et al., 1988). S. Typhimurium and E. coli strains were grown in LB broth with appropriate antibiotics. Antibiotics were used at the following concentrations unless otherwise indicated: ampicillin (Amp; $100 \mu \mathrm{g}$ $\left.\mathrm{ml}^{-1}\right)$, kanamycin $\left(\mathrm{Km} ; 50 \mu \mathrm{g} \mathrm{ml} \mathrm{g}^{-1}\right)$, nalidixic acid $(\mathrm{Nal} ; 20 \mu \mathrm{g}$ $\mathrm{ml}^{-1}$ ). Cultures were grown at $37^{\circ} \mathrm{C}$ with aeration in a rotary shaker unless otherwise indicated.

Experimental animals. All animal experiments were conducted according to the requirements of the Animals (Scientific Procedures) Act 1986 (licence 30/1998) and were approved by the local ethical review committee. Large White $\times$ Landrace crossbred pigs were obtained from an established Salmonella-free commercial farm. Pigs were housed in a medium containment unit and fed twice daily on a diet of antibiotic-free weaner pellets with water freely available. All experimental animals were confirmed to be culture-negative for Salmonella by enrichment of rectal swabs overnight in Rappaport and Selenite broth followed by subsequent culture on Brilliant Green agar (Oxoid) for $16 \mathrm{~h}$. Analysis of pre-vaccination serum IgG confirmed negligible levels of sero-reactivity to Salmonella in the animals used for vaccination and challenge studies.

In vivo screening of a ST4/74 Nal ${ }^{\mathrm{R}}$ STM mutant library. A library of 1045 signature-tagged mini-Tn $5 \mathrm{Km} 2$ transposon insertion mutants of ST4/74 Nal ${ }^{\mathrm{R}}$ previously described by Morgan et al. (2004) was used for this study. Eleven pools of 95 mutants were grown in LB broth in microtitre trays at $37{ }^{\circ} \mathrm{C}$ for $16 \mathrm{~h}$ with aeration. Aliquots were removed from each of the 11 pools and used for preparation of 'input pool' genomic DNA by the CTAB ( $N$-cetyl- $N, N, N$-trimethylammonium bromide) method (Hensel et al., 1995). For each pool, two 6week-old pigs were fasted for $12 \mathrm{~h}$ prior to infection and orally dosed with $\sim 10^{10}$ c.f.u. per input pool. A section of distal ileal mucosa, excluding Peyer's patches, was aseptically excised at post mortem examination 3 days post-infection and triplicate $1 \mathrm{~g}$ samples were homogenized in $9 \mathrm{ml} 0.9 \%$ saline. Bacteria (in excess of 10000 colonies) were recovered from homogenized ileal mucosa by plating onto MacConkey agar containing $\mathrm{Nal}$ and $\mathrm{Km}$. Bacteria were pooled and used for preparation of 'output pool' genomic DNA. Signature tags from input and output pools were amplified from genomic DNA using primers P2 (5'-TACCTACAACCTCAAGCTT-3') and P4 (5'TACCCATTCTAACCAAGC-3'). Tags were subsequently labelled with $\left[{ }^{32} \mathrm{P}\right] \mathrm{dCTP}$ by PCR as described previously (Morgan et al., 2004). $\left[{ }^{32} \mathrm{P}\right] \mathrm{dCTP}$ labelled signature-tag probes were hybridized to a corresponding pool of signature-tag PCR products amplified from each of 95 pUTmini-Tn $5 \mathrm{Km} 2$ plasmids using primers P6pair $\left(5^{\prime}\right.$ GATCAGATCTGGCCGCCTAGGC-3') and PXho (5'-TTATGAGCCATATTCAACGGG-3'). Dot blots and hybridizations were performed as described previously (Morgan et al., 2004). Duplicate dot blots were prepared for both input pools and output pools from each of two pigs to reduce artefacts.

For spiked pools, selected attenuated mutants identified in the primary screen, and colonization-proficient mutants with compatible tags, were picked into individual wells of 96 -well microtitre plates containing LB broth supplemented with $\mathrm{Nal}$ and $\mathrm{Km}$. All spiked pools contained less than $25 \%$ known attenuated mutants. Pools were tested in the STM pig infection model as described above.

Identification of colonization-defective mutants. Attenuated mutants were identified as producing a weaker hybridization signal in the output pool of at least one pig compared to the input pool, from duplicate dot blots, when compared by eye by two independent researchers. The site of the transposon insertion in attenuated mutants was then determined. EcoRI-, PstI- or EagI-restricted genomic DNA was ligated into similarly restricted pBluescript $\mathrm{KS}(+)$ and transformed into chemically competent $E$. coli TOP $10 \mathrm{~F}^{\prime}$. Sequencing of DNA flanking the transposon was performed by Lark Technologies using mini-Tn $5 \mathrm{Km} 2$ specific primers $\mathrm{P} 6\left(5^{\prime}\right.$ CCTAGGCGGCCAGATCTG-3') or P10 (5'-TCCTCTAGAGTCGACCTGC- $3^{\prime}$ ). The location of transposon insertions was identified by BLAST-N alignment using the GenBank, National Center for 
Biotechnology Information (NCBI, http://www.ncbi.nlm.nih.gov/) and coliBase (http://colibase.bham.ac.uk) databases. Sequence data are available from the authors on request.

In vivo co-infection study. Mixed infections with mutant and wildtype strains were used to confirm attenuation of a $S$. Typhimurium safA mutant. Cultures of wild-type ST4/74 Nal${ }^{\mathrm{R}}$ and a ST4/74 Nal${ }^{\mathrm{R}}$ safA : : mini-Tn5Km2 transductant (described below) were adjusted to the same $\mathrm{OD}_{600}$ and mixed in a $1: 1$ ratio prior to oral inoculation of two 6-week-old pigs. Each pig was challenged with a total dose of $10^{10}$ c.f.u. Post mortem examination was performed 5 days post-infection and bacteria were recovered from homogenized ileal mucosa by plating onto Brilliant Green agar containing $\mathrm{Nal}$ or Nal plus $\mathrm{Km}$ to enumerate the mutant strain. The number of viable wild-type bacteria was calculated by subtracting the count on $\mathrm{Nal}$ plus $\mathrm{Km}$ medium from that on the $\mathrm{Nal}$ plates. The ratio of mutant to wild-type bacteria recovered from ileal mucosa was compared to the ratio of mutant to wild-type bacteria in the original inoculum and the data were statistically analysed by $t$-test.

Transduction of safA : : mini-Tn5Km2 between strains of $S$. Typhimurium. A safA mutation was introduced into the archived $S$. Typhimurium ST4/74 $\mathrm{Nal}^{\mathrm{R}}$ strain by transduction with bacteriophage P22 HT/int. A donor lysate of P22 HT/int was prepared by the addition of phage to an exponential-phase LB culture of the original safA : : mini-Tn $5 \mathrm{Km} 2$ mutant strain at a m.o.i. of 0.03 . Cultures were reincubated for $3 \mathrm{~h}$ at $37{ }^{\circ} \mathrm{C}$ with shaking. Bacteria were removed by centrifugation at $11000 \mathrm{~g}$ for $10 \mathrm{~min}$ and the supernatant filtered through a $0.45 \mu \mathrm{m}$ filter. The resulting lysate was added to a broth culture of recipient $S$. Typhimurium ST4/74 Nal ${ }^{\mathrm{R}}$ at a m.o.i. of $\sim 0.8$. After static incubation at $37{ }^{\circ} \mathrm{C}$ for $30 \mathrm{~min}$, the mixture was plated onto $\mathrm{LB}$ agar containing $\mathrm{Nal}$ and $\mathrm{Km}$. Transposon insertion sites were confirmed by PCR and Southern blot analysis as described previously (Morgan et al., 2004) using transposon-specific primer P10 (as above) and gene-specific primer safA_for (5'-TGTTATTACCAGCCACGGATT-3'). The transduced mutant was checked for non-agglutination with $5 \%$ acriflavine $/ \mathrm{HCl}$ to confirm normal expression of lipopolysaccharide.

Preparation of secreted proteins. Secreted proteins were prepared from ST4/74 Nal ${ }^{\mathrm{R}}$ and ST4/74 Nal ${ }^{\mathrm{R}}$ prgH : : mini-Tn5Km2. Bacteria were grown to $\mathrm{OD}_{600} 1.0$ in Dulbecco's Modified Eagle's Medium (DMEM), cells pelleted by centrifugation $\left(8000 \mathrm{~g}, 15 \mathrm{~min}, 4{ }^{\circ} \mathrm{C}\right)$ and supernatants collected. Supernatants were filtered using $0.45 \mu \mathrm{m}$ pore size low-protein-binding filters (Millipore) and proteins were precipitated on ice with $10 \%(\mathrm{v} / \mathrm{v}$; final concentration) trichloroacetic acid for $1 \mathrm{~h}$. After centrifugation $\left(10000 \mathrm{~g}, 20 \mathrm{~min}, 22{ }^{\circ} \mathrm{C}\right)$ pellets were washed in ice-cold acetone and resuspended in PBS. At least four independent extractions for each vaccine preparation were pooled to minimize differences in protein recovery from sample to sample. After dialysis an aliquot from each vaccine preparation was removed and boiled in SDS buffer for $5 \mathrm{~min}$, followed by separation using $10 \%$ $(\mathrm{w} / \mathrm{v})$ SDS-PAGE to assess the yield, size and stability of proteins. Prior to vaccine formulation each protein preparation was analysed by Cambrex Bio Science to ensure that endotoxin levels were within recommended standards of the European Pharmacopeia (Ph.Eur.), which limits the endotoxin content of a porcine vaccine to $1 \times 10^{6}$ international endotoxin units (IEU) per dose (wild-type vaccine, $9 \times 10^{2}$ IEU per dose; $p r g H$ vaccine $2 \times 10^{3}$ IEU per dose).

As type III secreted proteins are a major component of wild-type secreted protein preparations, the protein profile of the $\mathrm{prgH}$ mutant was compared visually with the wild-type secreted protein profile to normalize the $\mathrm{prgH}$ preparation based on the relative concentrations of the FliC (flagellin) protein. Adjustments based on FliC levels were also confirmed to result in comparable levels of the secreted SPI-4-encoded $\sim 600 \mathrm{kDa}$ SiiE protein, thus equivalent levels of non-SPI-1 related secreted factors were represented in both vaccine formulations.
Experimental immunization and infection procedures. Vaccines were formulated 1:1 with Freund's incomplete adjuvant (SigmaAldrich) prior to immunization. On day 0 three groups of four 5-weekold pigs were immunized intramuscularly (i.m.) with either $100 \mu \mathrm{g}$ wild-type secreted protein vaccine, an equivalent quantity of $\mathrm{prgH}$ mutant vaccine, based on normalization relative to the FliC and SiiE proteins, or mock vaccine (PBS formulated with Freund's incomplete adjuvant) in a $1 \mathrm{ml}$ volume. Due to concerns regarding health status one pig was removed from the $\mathrm{prgH}$ vaccine group prior to immunization, reducing the $\mathrm{prgH}$ vaccine group size to 3 pigs. At day 22 each pig was given an i.m. booster vaccination of either $200 \mu \mathrm{g}$ wild-type secreted protein vaccine, an equivalent quantity of prgH mutant vaccine, or mock vaccine in a $1 \mathrm{ml}$ volume. At day 37 all pigs were challenged by oralgastric intubation with $5 \times 10^{9}$ c.f.u. ST4/74 $\mathrm{Nal}^{\mathrm{R}}$ in a $10 \mathrm{ml}$ volume administered with $10 \mathrm{ml}$ antacid [sterile double-distilled water containing $5 \%(\mathrm{w} / \mathrm{v}) \mathrm{Mg}\left(\mathrm{SiO}_{3}\right)_{3}, 5 \%$ (w/v) $\mathrm{NaHCO}_{3}$, and $5 \%(\mathrm{w} / \mathrm{v}) \mathrm{MgCO}_{3}$ ]. Clinical signs of infection, including pyrexia, general demeanour, fluid and food intake, faecal consistency and faecal content, were monitored twice daily for 6 days post-infection. Faecal excretion of ST4/74 Nal ${ }^{\mathrm{R}}$ was quantified by plating serial dilutions of faecal samples collected per rectum onto Brilliant Green agar containing Nal. Any pigs reaching predefined humane end points were humanely killed with an overdose of barbiturate. All other pigs were killed 6 days post-infection. Serum was obtained by bleeding from the anterior vena cava prior to primary vaccination (pre-immune), booster vaccination (pre-boost) and challenge (pre-infection). Blood sampling was also performed at post mortem examination.

ELISA. Maxisorp plates (NUNC, Fisher Scientific) were coated with carbonate buffer $\left(\mathrm{Na}_{2} \mathrm{CO}_{3} 10 \mathrm{mM} ; \mathrm{NaHCO}_{3} 35 \mathrm{mM}\right.$; pH 9.6) containing $0.5 \mu \mathrm{g} \mathrm{ml}^{-1}$ wild-type or an equivalent quantity of $\mathrm{prgH}$ mutant vaccine based on normalization relative to the FliC and SiiE for $16 \mathrm{~h}$ at $4{ }^{\circ} \mathrm{C}$. After washing three times with PBS-T [PBS plus $0.05 \%(\mathrm{v} / \mathrm{v})$ Tween 20] plates were blocked with PBS-T containing $3 \%(\mathrm{w} / \mathrm{v})$ BSA for $1 \mathrm{~h}$ at room temperature. Plates were washed a further three times with PBS-T and incubated for $1 \mathrm{~h}$ at room temperature with PBS-T plus $3 \%(\mathrm{w} / \mathrm{v})$ BSA containing diluted pig sera $(1: 100)$ collected on either day 0 (pre-immune), day 22 (preboost), day 37 (pre-infection) or day 43 (post mortem). Plates were washed as above and incubated with PBS-T plus $3 \%(\mathrm{w} / \mathrm{v})$ BSA and $1: 5000$ rabbit anti-swine IgG (whole molecule)-AP (Sigma-Aldrich) for $1 \mathrm{~h}$ at room temperature. Plates were washed as above and $50 \mu \mathrm{l} p$ nitrophenyl phosphate substrate added. Colour development was allowed to occur for $30 \mathrm{~min}$ and stopped with the addition of $3 \mathrm{M}$ $\mathrm{NaOH}$. The absorbance of each well was read at $405 \mathrm{~nm}$.

Statistical analysis. Statistical analyses of data were performed using the Statistical Analysis System (SAS Institute). Data were transformed exponentially, geometric means determined, and statistical significance of differences was calculated using parametric tests. An F-test with data taken as repeated measurements was used to determine whether administration of wild-type or $\mathrm{prgH}$ mutant vaccine resulted in a significant decrease in shedding of ST4/74 Nal ${ }^{\mathrm{R}}$ when compared with mock vaccination. Single comparisons between control and treatment means were made with a paired Student's twotailed $t$-test when appropriate. $P$ values of 0.05 or less were considered significant. All data are expressed as mean \pm SEM.

\section{RESULTS AND DISCUSSION}

\section{In vivo screening of an S. Typhimurium STM mutant library in pigs}

A library of ST4/74 $\mathrm{Nal}^{\mathrm{R}}$ signature-tagged mutants was screened for ability to colonize the intestinal tract in a 
porcine model of infection. In total 1045 signature-tagged mutants were screened in 11 pools of 95 mutants, with each pool screened in two pigs. Of the 1045 mutants screened, 119 mutants representing 95 genes were defective in colonization on the basis that they gave a weak or absent hybridization signal in the output pool recovered from intestinal mucosa of at least one animal. All mutant phenotypes are reported, since numerous mutants which exhibited varying levels of attenuation in replicate animals were significantly attenuated upon retesting in single infection studies (Morgan et al., 2004). Of the 119 attenuating mutations, the transposon insertion sites of 79 had previously been determined by Morgan et al. (2004) and were attenuated in calves, chickens or both species. The transposon insertion sites of 36 of the remaining 40 mutants were determined during the course of this study and all of these mutants were attenuated in the pig model only. Despite the use of three alternative restriction enzymes we were unable to subclone the remaining four mutants due to difficulties associated with cloning large DNA fragments, probably a consequence of excessive distance between restriction sites in the genome relative to those in the transposon. In addition to the 119 mutants attenuated in pigs, a further 108 mutants (with defects in a total of 83 different genes) that were attenuated in calves and/or chicks (Morgan et al., 2004) exhibited no defect in intestinal colonization of pigs (Table 1).

To confirm the attenuated phenotypes demonstrated in the primary screen a selection of transposon mutants representing Salmonella pathogenicity islands (SPIs) and fimbrial loci ( $p r g K, s s a Q, \operatorname{sugR}, m g t C, p i p C, s a f A, s t b C$, $s t b D$ ) were spiked into fresh pools of 95 among tagged but colonization-proficient mutants and retested in the pig infection model as described. All mutants were consistently attenuated in the second screen (Table 1).

Of the 119 mutants attenuated in pigs, 54 contained transposon insertions within known SPIs, with a striking 49 insertions located in 32 genes of SPIs-1 and -2. SPI-1 encodes T3SS-1 and a number of secreted translocator proteins and facilitates Salmonella invasion of host epithelial cells by injection of effector proteins into enterocytes that stimulate rearrangements of the subcortical actin cytoskeleton (Galan \& Curtiss, 1989; Galan, 1996; Jones \& Falkow, 1994). T3SS-1-secreted effectors also act in concert to influence the induction of enteritis (Drecktrah et al., 2005; Galyov et al., 1997; Zhou \& Galan, 2001). SPI-2 encodes T3SS-2 and expression of T3SS-2 and associated effectors facilitates the persistence of intracellular bacteria within membrane-bound Salmonella-containing vacuoles (Hensel et al., 1995; Hensel, 2000; Shea et al., 1996).

The isolation of multiple independent attenuating mutations in structural and secreted components of T3SS-1 and T3SS-2 markedly reduces the likelihood that attenuation of SPI- 1 or -2 mutants is due to second-site or polar effects. Furthermore, our data support a recent study in which a
SPI-1 $\operatorname{sip} B:: \operatorname{kan}^{\mathrm{R}}$ mutant was found to be significantly impaired in its ability to colonize the intestines of pigs following oral inoculation and to invade porcine intestinal mucosa in ligated ileal loops (Boyen et al., 2006b).

An attenuated mutant with a transposon insertion in safA was identified in our screen. The safABCD operon is located within Salmonella enterica centisome 7 genomic island (SCI), also known as SPI-6 in Salmonella Typhi (Folkesson et al., 2002; Parkhill et al., 2001) and encodes Salmonella-specific putative atypical fimbriae. Although the safA mutant was attenuated in our pig model it was not attenuated in a similar STM study in calves and chickens and the $S$. Typhimurium saf operon was not required for virulence in mice (Folkesson et al., 1999; Morgan et al., 2004). This may reflect the ability of bacteria to express different adhesins to exploit different animal hosts. To our knowledge this is the first evidence for a role in vivo for this island.

To further validate the STM screen and confirm the role of SafA, two pigs were orally inoculated with a mixed inoculum of the wild-type and a P22 transductant harbouring a safA:: mini-Tn5Km2 mutation that was found to be attenuating in one of two pigs in the primary screen. The ratio of safA mutant to wild-type strain recovered from ileal mucosa 5 days post-infection $\left[0.84 \pm 0.014\right.$ (mutant $\log _{10}$ c.f.u. $\mathrm{g}^{-1} /$ wild-type $\log _{10}$ c.f.u. $\mathrm{g}^{-1} \pm$ SEM)] was significantly different to the ratio of safA mutant to wild-type strain in the initial inoculum $(0.92 \pm 0$; $P<0.001$ ); however, no statistically significant differences in the magnitude or duration of faecal excretion of the mutant strain relative to the parent were detected (data not shown). The consistent attenuation caused by the safA mutation detected at the site of recovery of STM output pools suggests a subtle role for Saf fimbriae in intestinal colonization and confirms that the screen sensitively detects meaningful phenotypes.

Of the other fimbrial mutants present within the mutant bank only $s t b C$ and $s t b D$ mutants were attenuated. Despite evidence that type I fimbriae play a role in the colonization of pigs (Althouse et al., 2003), a fimZ mutant was not attenuated in our screen. However, it is likely that differences in strain, mutation, inoculation dose, mode of delivery and sampling points between the studies account for the disparity in results. Mutation of fim $Z$ reduces expression of type I fimbriae, but simultaneously increases flagella-mediated motility (Clegg \& Hughes, 2002), and we consider that it would be unsafe to directly compare our findings to the role established for the type I fimbriae major subunit (FimA) described previously (Althouse et al., 2003).

Three of the mutants attenuated in the STM screen had transposon insertions in Salmonella pathogenicity island 3 (SPI-3) genes: $\operatorname{sugR,~misL~and~} m g t C$. SPI-3 is thought to have evolved by a multi-step evolutionary process and its phylogenetic distribution within S. enterica is not uniform. Not surprisingly therefore SPI-3 has a mosaic organization 
Table 1. Colonization phenotypes of STM mutants screened in a pig intestinal colonization model

\begin{tabular}{|c|c|c|c|}
\hline Classification & Gene name ${ }^{\star}$ & Proven or predicted function & $\begin{array}{c}\text { Colonization } \\
\text { phenotype } \dagger\end{array}$ \\
\hline \multicolumn{4}{|l|}{ SPI associated genes } \\
\hline \multirow[t]{16}{*}{ SPI-1 } & $\operatorname{org} A \ddagger$ & Type III secretion & - \\
\hline & $\operatorname{prgK\$ }$ & Type III secretion & - \\
\hline & $\operatorname{prgH}$ & Type III secretion & - \\
\hline & hilD $\ddagger$ & Type III secretion regulator & - \\
\hline & hilA & Type III secretion regulator & - \\
\hline & $\operatorname{sip} A \ddagger$ & Secreted protein & - \\
\hline & $\operatorname{sip} D$ & Secreted protein & - \\
\hline & $\operatorname{sip} C$ & Secreted protein & - \\
\hline & $\operatorname{sic} A \ddagger$ & Type III secretion & - \\
\hline & spaR & Type III secretion & - \\
\hline & spaO & Type III secretion & - \\
\hline & invI & Type III secretion & - \\
\hline & $i n v C$ & Type III secretion & - \\
\hline & invE & Type III secretion & - \\
\hline & $i n v F$ & Type III secretion & - \\
\hline & invH & Type III secretion & - \\
\hline \multirow[t]{17}{*}{ SPI-2 } & $s s r B \ddagger$ & Type III secretion regulator & - \\
\hline & $s s r A \ddagger$ & Type III secretion regulator & - \\
\hline & $s s a B$ & Type III secretion & - \\
\hline & $s s a C$ & Type III secretion & wt \\
\hline & $s s a D \ddagger$ & Type III secretion & - \\
\hline & sseAll & Type III secretion & - \\
\hline & sseC & Secreted protein & - \\
\hline & $s s a G$ & Type III secretion & - \\
\hline & ssaj‡ & Type III secretion & - \\
\hline & STM1410 & Unknown & - \\
\hline & $s s a K$ & Type III secretion & - \\
\hline & ssaL & Type III secretion & - \\
\hline & $s s a M \ddagger$ & Type III secretion & - \\
\hline & $s s a V$ & Type III secretion & - \\
\hline & ssaQS & Type III secretion & - \\
\hline & $s s a R$ & Type III secretion & - \\
\hline & ssaS & Type III secretion & - \\
\hline \multirow[t]{6}{*}{ SPI-3 } & $\operatorname{sugRS}$ & ATP-binding protein & - \\
\hline & $r m b A$ & Putative cytoplasmic protein & wt \\
\hline & misL $L$ & Autotransporter protein & - \\
\hline & $s l s A \ddagger \|$ & Putative inner membrane protein & wt \\
\hline & $m g t C S$ & $\mathrm{Mg}^{2+}$ transport protein & - \\
\hline & STM3784 & Putative phosphotransferase system & wt \\
\hline \multirow[t]{3}{*}{ SPI-4 } & siiD & Putative membrane transporter & wt \\
\hline & $\operatorname{sii} E \ddagger \S$ & Putative inner membrane protein & $\mathrm{wt} /-$ \\
\hline & siiF‡ & Putative membrane transporter & wt \\
\hline \multirow[t]{2}{*}{ SPI-5 } & pipB‡॥ & TTSS-2 translocated protein & wt \\
\hline & $\operatorname{pip} C(\operatorname{sig} E) \S$ & SopB specific chaperone & - \\
\hline SPI-6 & safa\ & Fimbrial subunit & - \\
\hline \multirow{5}{*}{$\begin{array}{l}\text { Non SPI-encoded virulence-associated } \\
\text { genes }\end{array}$} & $\operatorname{sifB}$ & TTSS-2 translocated effector protein & wt \\
\hline & sopE2‡ & TTSS- 1 translocated protein & wt \\
\hline & mig-14 & Resistance to anti-microbial peptides & wt \\
\hline & sseK1 & TTSS-2 translocated effector protein & - \\
\hline & steC & Effector protein & wt \\
\hline \multirow{5}{*}{ Cell envelope } & $r f b P$ & Lipopolysaccharide synthesis & wt \\
\hline & $r f b K$ & Lipopolysaccharide synthesis & - \\
\hline & $r f b N$ & Lipopolysaccharide synthesis & - \\
\hline & $r f b U$ & Lipopolysaccharide synthesis & wt \\
\hline & $r f b H$ & Lipopolysaccharide synthesis & - \\
\hline
\end{tabular}


Table 1. cont.

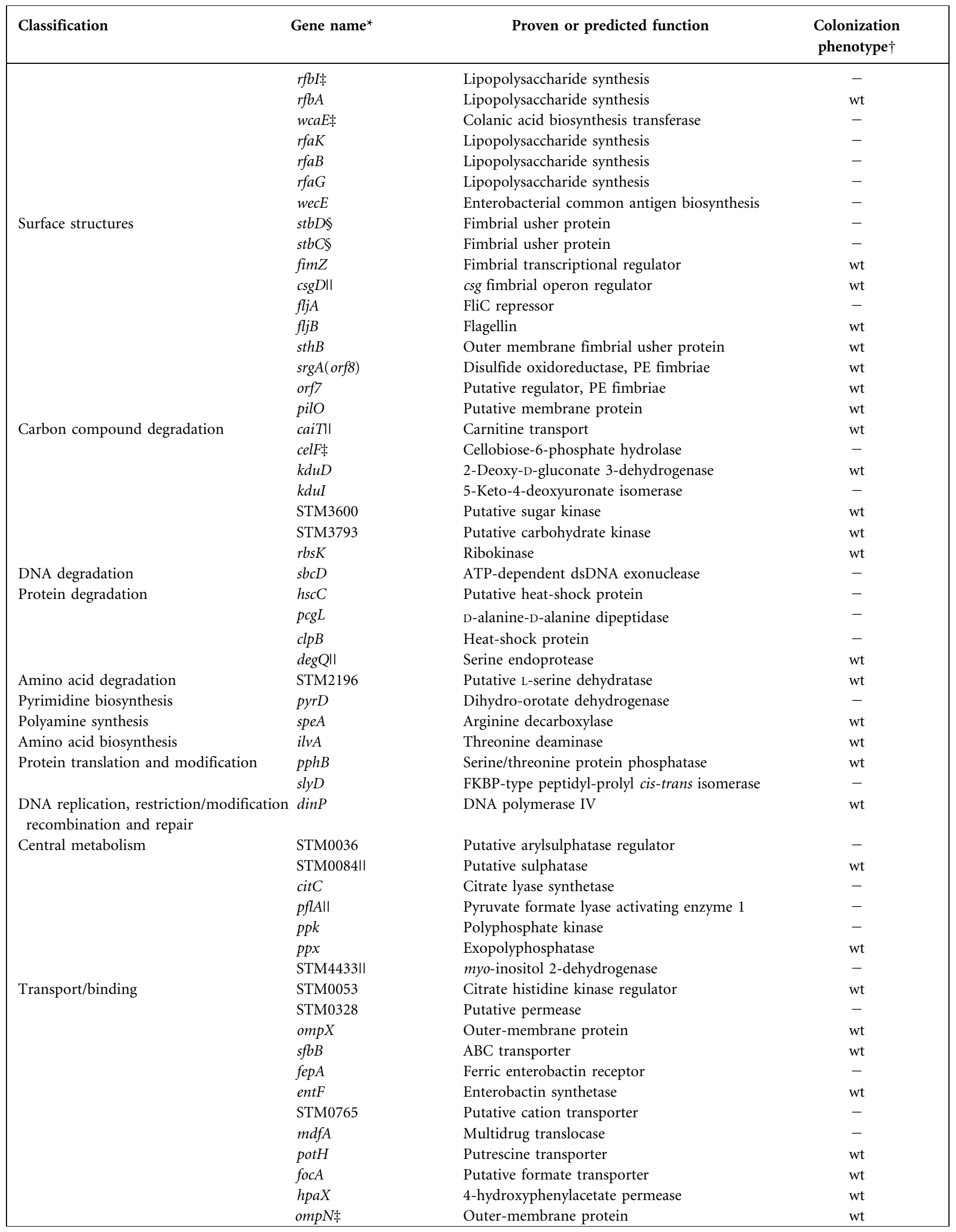


Table 1. cont.

\begin{tabular}{|c|c|c|c|}
\hline Classification & Gene name ${ }^{\star}$ & Proven or predicted function & $\begin{array}{c}\text { Colonization } \\
\text { phenotype } \dagger\end{array}$ \\
\hline \multirow{19}{*}{$\begin{array}{l}\text { Chemotaxis and motility } \\
\text { Regulatory }\end{array}$} & chaA & Sodium-calcium/proton antiporter & wt \\
\hline & his $M$ & Histidine transport system permease & wt \\
\hline & $c a d B$ & Putative cadaverine-lysine antiporter & - \\
\hline & STM2574 & Putative permease & - \\
\hline & $g a b P$ & Gamma-aminobutyrate permease & wt \\
\hline & emrA & Multidrug resistance secretion protein & wt \\
\hline & $\operatorname{trk} A$ & Potassium transport protein & wt \\
\hline & yneA & $\mathrm{ABC}$ transport protein & wt \\
\hline & STM1657 & Putative chemoreceptor protein & wt \\
\hline & $y b d O$ & Putative transcriptional regulator & wt \\
\hline & $d p i A$ & Two-component system response regulator & - \\
\hline & STM1127II & Putative transcriptional regulator & wt \\
\hline & celD & Putative $c e l$ operon repressor & wt \\
\hline & $h n s$ & DNA binding protein; pleiotropic regulator & - \\
\hline & $k d g R$ & Probable global regulatory protein & wt \\
\hline & relA & GTP pyrophosphokinase & wt \\
\hline & $\operatorname{agaR}$ & aga operon transcriptional regulator & wt \\
\hline & STM3602 & Putative transcriptional regulator & - \\
\hline & yjjQ & Putative transcriptional regulator & wt \\
\hline \multirow[t]{4}{*}{ Phage-associated } & STM1043 & Gifsy-2 prophage & wt \\
\hline & STM2243 & Putative phage tail fibre protein & - \\
\hline & STM2586 & Gifsy-1 prophage & wt \\
\hline & STM2587 & Gifsy-1 prophage & wt \\
\hline \multirow[t]{2}{*}{ Plasmid functions } & traMll & Plasmid transfer & wt \\
\hline & Unknown & Homology to $\mathrm{pHCM} 1$ replication protein & - \\
\hline \multirow{14}{*}{ Unknown function } & yaiU & Putative autotransporter protein & - \\
\hline & $y b a J$ & Putative cytoplasmic protein & - \\
\hline & $y d j A$ & Putative nitroreductase & - \\
\hline & STM1527 & Putative inner membrane protein & - \\
\hline & STM1540 & Putative secreted hydrolase & wt \\
\hline & STM1548 & Putative isomerase & wt \\
\hline & $y c i F$ & Putative cytoplasmic protein & - \\
\hline & pagO & Putative integral membrane protein & - \\
\hline & pagk & Putative PhoPQ-activated protein & - \\
\hline & yeeI & Putative inner membrane protein & - \\
\hline & $y g c F$ & Putative organic radical activating enzyme & wt \\
\hline & STM2503 & Putative diguanylate cyclase & - \\
\hline & STM3031II & Ail/OmpX homologue & wt \\
\hline & $y i g F$ & Putative inner membrane protein & - \\
\hline \multirow[t]{17}{*}{ Hypothetical proteins } & STM0037 & Conserved hypothetical & wt \\
\hline & STM0080 & Conserved hypothetical & wt \\
\hline & STM0082 & Conserved hypothetical & wt \\
\hline & STM0438 & Conserved hypothetical & - \\
\hline & STM0557 & Conserved hypothetical & - \\
\hline & STM0731 & Hypothetical & wt \\
\hline & $y b h M$ & Conserved hypothetical & - \\
\hline & STM1228 & Hypothetical & wt \\
\hline & STM1630 & Conserved hypothetical & wt \\
\hline & STM1668末 & Hypothetical & - \\
\hline & STM1672II & Hypothetical & wt \\
\hline & STM1698 & Hypothetical & wt \\
\hline & $y n a F$ & Conserved hypothetical & - \\
\hline & STM1864末 & Conserved hypothetical & - \\
\hline & $\mathrm{araH}$ & Conserved hypothetical & wt \\
\hline & STM2245 & Hypothetical & - \\
\hline & STM2743 & Hypothetical & wt \\
\hline
\end{tabular}


Table 1. cont.

\begin{tabular}{|c|c|c|c|}
\hline Classification & Gene name ${ }^{\star}$ & Proven or predicted function & $\begin{array}{c}\text { Colonization } \\
\text { phenotype } \dagger\end{array}$ \\
\hline & STM2761 & Conserved hypothetical & wt \\
\hline & STM3026 & Hypothetical & wt \\
\hline & STM3030末 & Conserved hypothetical & wt \\
\hline & $y f g Z$ & Conserved hypothetical & - \\
\hline & $y r d B$ & Conserved hypothetical & wt \\
\hline & STM4198 & Conserved hypothetical & - \\
\hline & STM4199 & Hypothetical & wt \\
\hline & STM4302 & Hypothetical & wt \\
\hline & STM4316 & Hypothetical & - \\
\hline & pSLT026 & Hypothetical & wt \\
\hline
\end{tabular}

${ }^{\star}$ The STM and pSLT prefixes indicate gene name/number on the chromosome and virulence plasmid as assigned by S. Typhimurium strain LT2 complete genome sequencing project.

†wt indicates that the mutant exhibited no apparent defect in intestinal colonization of pigs despite previous attenuation in calves and/or chicks (Morgan et al., 2004); - denotes mutants showing attenuated intestinal colonization in pigs; wt/- indicates both attenuated and wild-type phenotypes observed for different mutants of the same gene.

¥Indicates multiple mutants isolated.

SIndicates mutants rescreened.

IIIndicates insertion site upstream of gene.

and encodes a group of functionally unrelated proteins (Amavisit et al., 2003; Blanc-Potard et al., 1999). sugR lies within the phylogenetically variable region of SPI-3 and encodes a putative ATP-binding protein (Blanc-Potard et al., 1999). Very little is known about $\operatorname{sugR}$ and this is the first evidence of a role in vivo for this gene. misL encodes an autotransporter protein, similar to the AIDA-I adhesin of enteropathogenic E. coli, which plays a role in the intestinal colonization of chickens and mice (Blanc-Potard et al., 1999; Dorsey et al., 2005; Morgan et al., 2004). The exact function of MisL in vivo is unclear; however, recently Dorsey et al. (2005) identified fibronectin as a host ligand for MisL, suggesting that MisL may be involved in bacterial attachment during colonization. The $m g t C$ gene encodes an integral membrane protein of unknown function that is required for systemic virulence in mice (Blanc-Potard \& Groisman, 1997). $m g t C$ forms part of an operon with $m g t B$, which encodes a P-type ATPase that mediates the influx of $\mathrm{Mg}^{2+}$ (Snavely et al., 1991). It has been suggested that, due to its genetic association with $m g t B, \mathrm{MgtC}$ might function as a $\mathrm{Mg}^{2+}$ transporter but it has since been shown that $\mathrm{MgtC}$ is neither required for, nor influences, $\mathrm{MgtB}$ transport activity (Blanc-Potard \& Groisman, 1997; Moncrief \& Maguire, 1998). Recent studies suggest that serovar Typhimurium MgtC may be involved in regulating host or bacterial cell membrane potential and therefore may play a role in influencing cellular ion homeostasis during infection (Gunzel et al., 2006). The attenuation of the $m g t C$ mutant in our screen is the first in vivo role assigned to this gene using an intestinal colonization model.
A further three mutants with insertions in SPI-3 genes ( $r m b A$, slsA and STM3784) were known to be present in the mutant bank used in this study, but these mutants did not appear to be attenuated in pigs. This result mirrors those obtained with previous screens in calves and chickens in that different SPI-3-encoded genes do not consistently play a role in colonization or host-specificity (Morgan et al., 2004).

In previous studies SPI- 4 was found to be required for colonization of calf ileum but not caecal colonization of chickens (Morgan et al., 2004). The present study suggests that SPI-4 does not play an important role in intestinal colonization in pigs as only 1 of the 11 SPI- 4 insertion mutants in the library was attenuated. A total of eight mutants with defects in siiE (which encodes a secreted $\sim 600 \mathrm{kDa}$ protein; Morgan et al., 2007) were screened, of which seven colonized well and one was attenuated. As the SPI-4 mutants tested were present in different pools it is possible that variations in competition dynamics between mutants in a given pool may have dictated why only one of the siiE mutants was lost during colonization of pigs. Taken together, the data support the notion that SPI-4 is specifically required for colonization of bovine intestines (Morgan et al., 2004).

One of the mutants attenuated in this screen had a transposon insertion in the pipC gene (also known as sigE). $p i p C$ is one of six genes found on SPI-5, a $7.6 \mathrm{~kb}$ island known to play a role in enteropathogenesis of Salmonella (Wood et al., 1998). pipC was originally identified in an 
in vitro screen for invasion genes and encodes a chaperone specifically required for the stability and/or secretion of SPI-1 effector protein SopB (also known as SigD) also encoded on SPI-5 (Darwin et al., 2001; Galyov et al., 1997; Hong \& Miller, 1998). SopB is an inositol phosphate phosphatase and modulates cell signalling to induce enteritis in concert with other effectors (Galyov et al., 1997; Norris et al., 1998). Interestingly the pipC mutant was not previously attenuated for colonization in calves (Morgan et al., 2004). An additional mutant with an insertion in the SPI-5 pipB gene was also present in the mutant bank used in this study. PipB is an effector protein secreted by T3SS-2, required for colonization of chickens but not calves (Morgan et al., 2004). In the pig model this mutant was not attenuated, suggesting that this effector may not play a role in the colonization of swine.

The role of LPS in virulence has been well documented in STM-based studies of Gram-negative pathogens in foodproducing animals (Dziva et al., 2004; Morgan et al., 2004; van Diemen et al., 2005). As expected, several S. Typhimurium mutants predicted to be impaired in LPS biosynthesis were found to be attenuated in pigs. The precise role of LPS in colonization is difficult to determine as in addition to its predicted role in providing protection against host defence mechanisms LPS also plays an important role in ensuring the correct insertion, folding and stability of membrane proteins and other surfaceanchored molecules involved in colonization (Raetz \& Whitfield, 2002).

Three of the attenuated mutants (pagO, pagK and STM1864) identified in our screen had insertions in genes located within a putative phage remnant known to contain the T3SS-1 effector gene sopE2 (McClelland et al., 2001). pagO and $\operatorname{pagK}$ were originally identified as PhoP-PhoQactivated genes by $\operatorname{Tn} p h o A$ mutagenesis; however, little is known about their role during infection (Belden \& Miller, 1994). The Salmonella PhoP-PhoQ system is a twocomponent regulatory system known to regulate, positively and negatively, a number of genes involved in virulence, growth at low $\mathrm{Mg}^{2+}$ concentrations, and resistance to antimicrobial peptides, bile salts and acid $\mathrm{pH}$ (Garcia Vescovi et al., 1996; Groisman, 2001; van Velkinburgh \& Gunn, 1999). The pagO gene encodes a predicted membrane protein which shows homology to $\mathrm{PagO}$ from Klebsiella pneumoniae and a product of the Yersinia virulence plasmid and is a member of the drug/metabolite exporter (DME) superfamily (Jack et al., 2001). In contrast, pagK shows no homology to any publicly available database sequences. STM1864, which is also regulated by PhoPPhoQ, encodes a predicted membrane protein containing a conserved domain common to proteins involved in processes requiring disulphide bond formation (Monsieurs et al., 2005). Such proteins are often involved in processes such as post-translational modification, protein turnover and protein stability. Interestingly this mutant was also attenuated in a calf colonization model (Morgan et al., 2004).
Other PhoP-PhoQ-regulated genes were identified in this screen, including the SPI-3 mgtC gene, $p c g L$, sseK1 which encodes a T3SS-2 secreted effector protein, pSLT026 and a number of SPI-2 encoded genes (Bijlsma \& Groisman, 2005; Monsieurs et al., 2005). The identification of PhoPPhoQ-regulated genes in our model raises the possibility that this system may be required for colonization of pigs by Salmonella.

\section{Assessment of secreted proteins as subunit vaccine candidates}

Based on the finding that numerous secreted and surfaceanchored molecules contribute to intestinal colonization of pigs by $S$. Typhimurium and the fact that vaccines based on extracellular and type III secreted proteins have shown promise against other pathogens, including $Y$. pestis (Leary et al., 1995) and E. coli O157 : H7 (Potter et al., 2004), we sought to determine if vaccines based on secreted components of $S$. Typhimurium are protective in pigs. In order to evaluate the protective effect of these proteins in reducing faecal shedding of $S$. Typhimurium we vaccinated pigs with secreted protein vaccines from wild-type ST4/74 $\mathrm{Nal}^{\mathrm{R}}$ or a mock vaccine as described in Methods. To evaluate the role of T3SS-1-secreted proteins in protection a further cohort of pigs was vaccinated in parallel with secreted proteins prepared from a $\operatorname{prgH}:: \operatorname{mini}-\mathrm{Tn} 5 \mathrm{Km} 2$ T3SS- 1 mutant under identical conditions and normalized for protein content to FliC and SiiE (Fig. 1). PrgH is an inner-membrane protein which forms part of the T3SS-1 needle complex required for injection of effector proteins

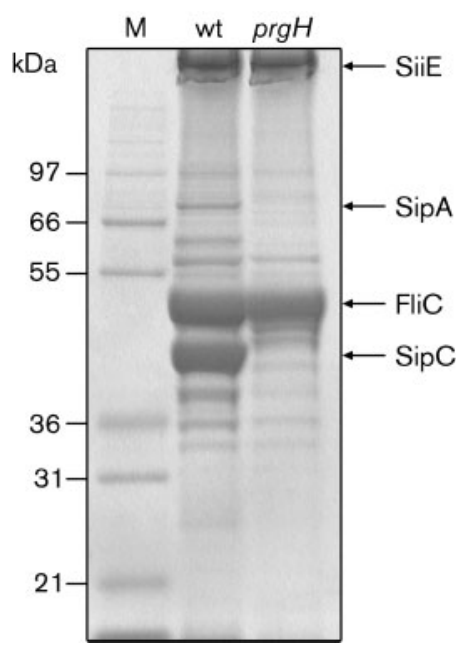

Fig. 1. SDS-10\% PAGE gel of secreted protein vaccine preparations from ST4/74 $\mathrm{Nal}^{R}$ (lane 2) and ST4/74 $\mathrm{Nal}^{R}$ prgH : : mini-Tn5Km2 (lane 3). Proteins were separated by SDS-10\% PAGE using Mark 12 pre-stained standards (Invitrogen; lane 1) and stained with Gelcode Blue (Pierce). Representative type III secreted Sip proteins, FliC and SiiE are indicated. 


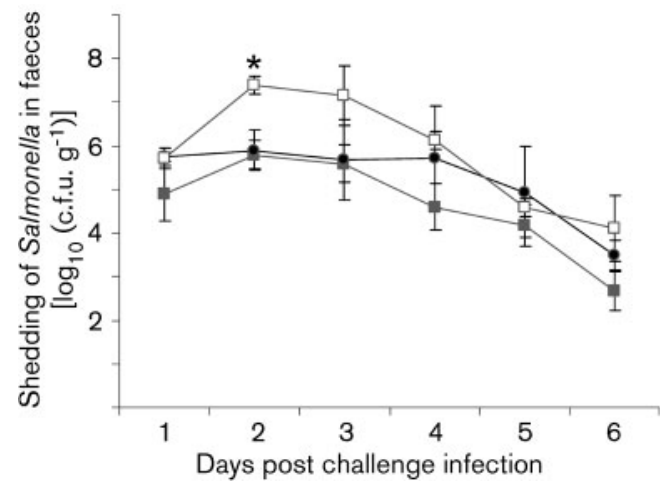

Fig. 2. Course of faecal excretion of $S T 4 / 74 \mathrm{Nal}^{\mathrm{R}}$ in pigs vaccinated with wild-type secreted protein vaccine $(\boldsymbol{\square}), \mathrm{prgH}$ mutant secreted protein vaccine $(\bullet)$ and mock vaccine $(\square)$. The error bars indicate SEM. $\left(^{*}\right)$ indicates significant differences $(P<0.05)$ between vaccinated and mock-vaccinated pigs.

into host cells (Kubori et al., 2000). The prgH mutant used for vaccine preparation was shown to be attenuated in our pig model of infection (Table 1).

All pigs were challenged orally with wild-type ST4/74 $\mathrm{Nal}^{\mathrm{R}}$ following vaccination. Post-challenge, all animals displayed clinical signs of salmonellosis and shed ST4/74 Nal${ }^{\mathrm{R}}$ from $24 \mathrm{~h}$ post-infection (Fig. 2). Clinical signs of infection, primarily general demeanour, were more pronounced in the mock-vaccinated group with two of the pigs from this group reaching their humane end point at day 39 (2 days post-infection). Faecal shedding in all groups peaked 2 days post-infection (day 39) and although pigs from both the wild-type-vaccine and $\mathrm{prgH}$-vaccine groups shed lower numbers of ST4/74 Nal${ }^{\mathrm{R}}$ when compared with the mockvaccinated animals at this time point $(P=0.0325$ and $P=0.0615$ respectively) only the reduction displayed by wild-type-vaccinated pigs was statistically significant. Wildtype-vaccinated and $\operatorname{prgH}$-vaccinated pigs also shed lower numbers of ST4/74 $\mathrm{Nal}^{\mathrm{R}}$ when compared with mock-vaccinated pigs on days 1, 3, 4 and 6 post-challenge; however, no statistically significant differences were observed (Fig. 2).

At post mortem examination ST4/74 $\mathrm{Nal}^{\mathrm{R}}$ was recovered from selected ileal, caecal and colonic sites (Fig. 3). There was no significant difference in the number of bacteria recovered from mucosal tissues and lymph nodes between all groups; however, animals vaccinated with the wild-type vaccine and $\operatorname{prgH}$ vaccine had lower numbers of ST4/74 $\mathrm{Nal}^{\mathrm{R}}$ in ileal, caecal and colonic contents when compared with the mock-vaccinated animals (Fig. 3). The difference in ST4/74 Nal ${ }^{\mathrm{R}}$ recovered from ileal and colonic contents from wild-type vaccinated animals when compared with mock-vaccinated animals was statistically significant $(P<0.05$; Fig. 3).

Although the present study indicated that our secreted protein vaccines did not confer long-term protection we were able to demonstrate a significant reduction in faecal shedding during the acute phase of infection and a lessening of disease severity. As the $\operatorname{prgH}$ vaccine also reduced shedding during this phase of infection [albeit that this was not significant at the $95 \%$ confidence interval $(P=0.0615)]$, it is likely that factors unrelated to T3SS-1 secreted proteins contributed to this effect.

\section{Serum IgG response}

Serum IgG responses induced by secreted protein vaccines were analysed by ELISA and are summarized in Fig. 4. Vaccination by the intramuscular route resulted in the induction of primary and secondary serum antibody responses to proteins secreted by both ST4/74 $\mathrm{Nal}^{\mathrm{R}}$ and the $\operatorname{prgH}$ mutant. Using the wild-type secreted protein vaccine as antigen, serum from pigs vaccinated with wildtype vaccine or $\mathrm{prgH}$ vaccine showed significantly higher reactivity than serum from mock-vaccinated pigs $(P<0.01$; Fig. 4a). Similarly using the $\operatorname{prg} H$ vaccine as antigen produced comparable levels of reactivity against serum from both wild-type and $\operatorname{prgH}$ vaccinated pigs (Fig. 4b).

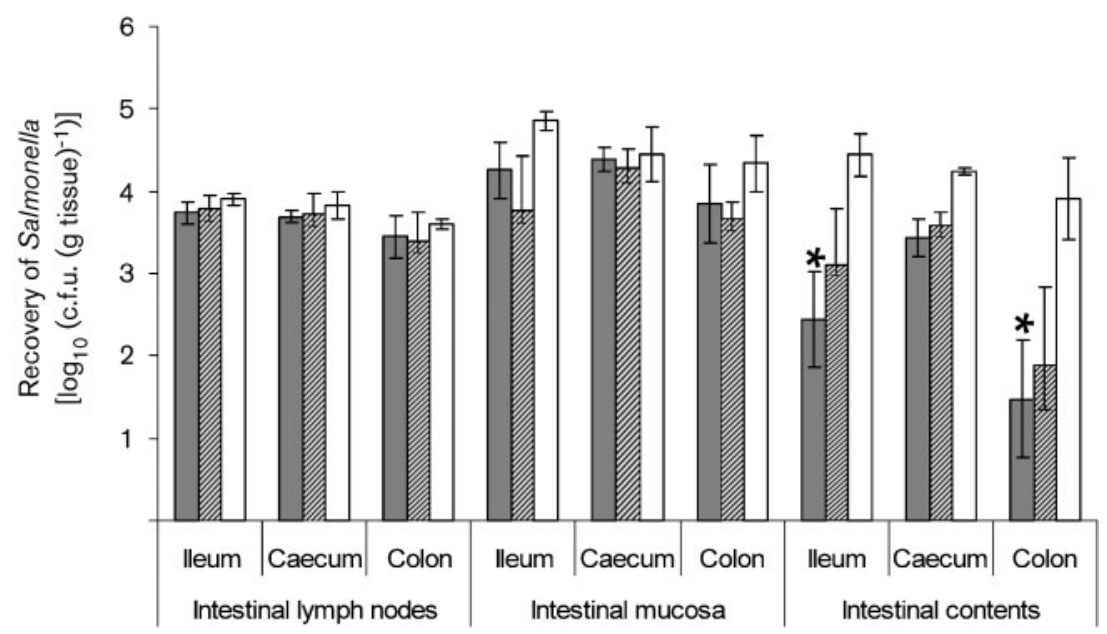

Fig. 3. Recovery of ST4/74 $\mathrm{Nal}^{\mathrm{R}}$ from intestinal lymph nodes, mucosa and contents of pigs vaccinated with wild-type secreted protein vaccine (grey bars), prgH mutant secreted protein vaccine (hatched bars) and mock vaccine (open bars) followed by oral challenge with ST4/74 $\mathrm{Nal}^{\mathrm{R}}$. $\left(^{*}\right)$ indicates significant differences $(P<0.05)$ between vaccinated and mock-vaccinated pigs. The error bars indicate SEM. 


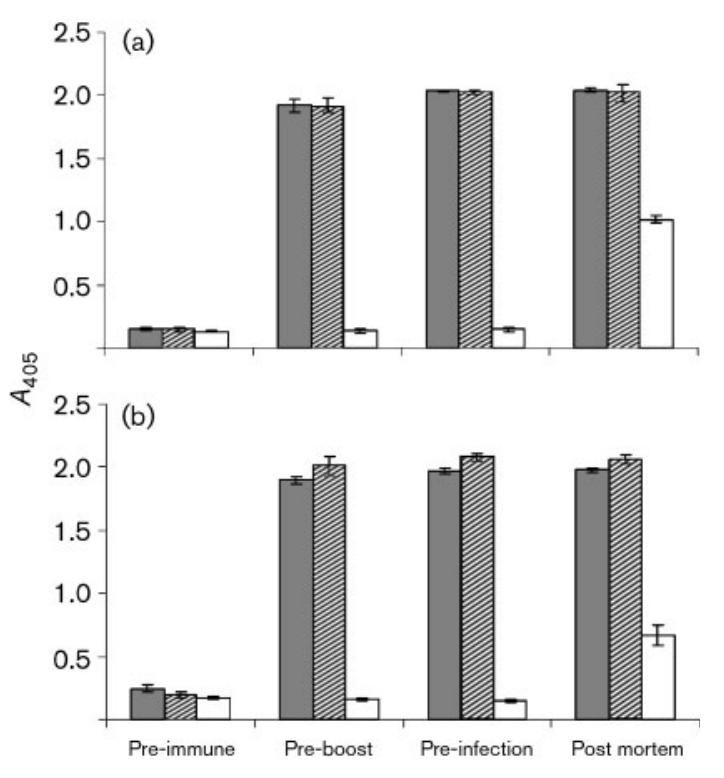

Fig. 4. Serum $\lg$ responses in pigs vaccinated with proteins from wild-type ST4/74 $\mathrm{Nal}^{\mathrm{R}}$ and ST4/74 $\mathrm{Nal}^{\mathrm{R}} \mathrm{prgH}$ : : miniTn5Km2. Serum samples from pigs vaccinated with ST4/74 $\mathrm{Nal}^{R}$ secreted protein preparation (grey bars), prgH mutant secreted protein preparation (hatched bars) and mock vaccine (open bars) were collected on day 0 (pre-immune), day 22 (pre-boost), day 37 (pre-infection) and day 43 (post mortem) diluted 1:100; and subjected to ELISA. ELISA plates were coated with (a) ST4/74 $\mathrm{Nal}^{\mathrm{R}}$ secreted protein vaccine or (b) prgH mutant secreted protein vaccine. IgG immune responses induced by the vaccines were determined. The error bars indicate SEM.

Serum from mock-vaccinated pigs showed minimal reactivity with both wild-type and $\mathrm{prgH}$ mutant secreted protein vaccines (Fig. 4).

To define further the serum IgG responses, wild-type and prgH mutant vaccine preparations were separated by $10 \%$ SDS-PAGE, transferred to nitrocellulose and probed with sera taken from vaccinated animals over the course of this study (Fig. 5). Vaccination with wild-type vaccine resulted in the induction of antibody response to known T3SS-1 secreted proteins (Fig. 5b); however, such responses were absent in pigs vaccinated with $\operatorname{prgH}$ mutant and mock vaccine (Fig. 5a, c).

Vaccines based on secreted components of other Gramnegative pathogens have shown promise. For example, vaccination of calves using secreted proteins from E. coli O157 : H7 generated responses against type III secreted proteins and was protective against experimental challenge (Potter et al., 2004) and in the field (A. Potter, personal communication). Further studies to dissect the basis of protection and optimize the vaccine dose, adjuvant and route of delivery of the vaccine used in this study are therefore warranted. It is also possible that additional factors combined with this vaccine preparation may be

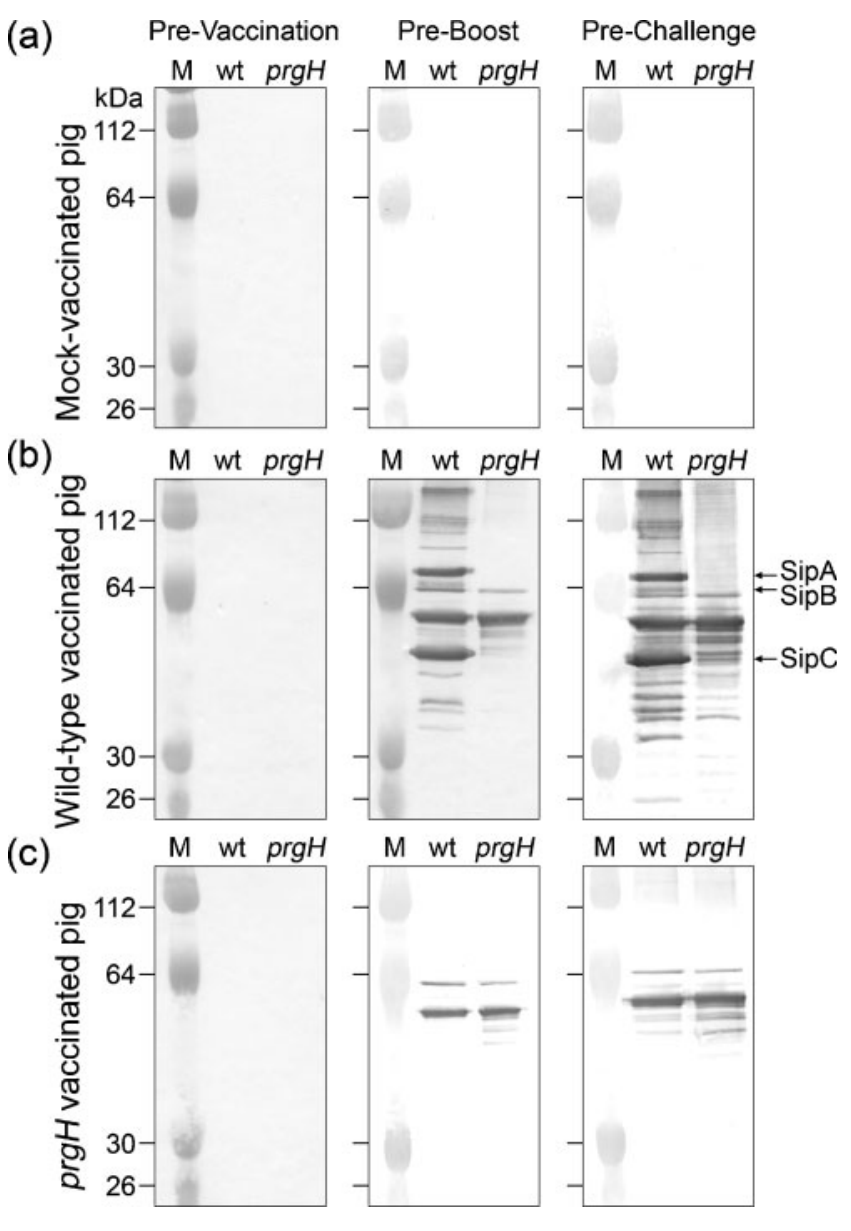

Fig. 5. Immunoblot analysis of sera from pigs vaccinated with ST4/74 Nal ${ }^{R}$ secreted protein preparation, prgH mutant secreted protein preparation or mock vaccine. Each blot contains kaleidoscope pre-stained standards (Bio-Rad; lane 1), secreted proteins from wild-type ST4/74 $\mathrm{Nal}^{\mathrm{R}}$ (lane 2) and secreted proteins from $\mathrm{ST} 4 / 74 \mathrm{Nal}^{\mathrm{R}}$ prgH : : mini-Tn5Km2 (lane 3). Proteins were separated by SDS-10\% PAGE, transferred to nitrocellulose and probed with representative sera from one animal from each group taken on days 0,22 and 37 of the study (pre-vaccination, preboost and pre-challenge respectively). (a) Mock-vaccinated group, (b) wild-type vaccinated group, (c) prgH-mutant vaccinated group.

required to improve levels of protection, as suggested by the multi-factorial nature of colonization in pigs highlighted by the STM screen.

In conclusion, this study has provided a better understanding of the host-specific requirements for establishment of $S$. Typhimurium infection in a key reservoir host and identified numerous genes with previously unrecognized roles in colonization. Inert vaccines that exploit the pivotal role of secreted components conferred limited protection against intestinal colonization and the basis of the protective effect remains to be elucidated. 


\section{ACKNOWLEDGEMENTS}

We gratefully acknowledge the support of the Department for the Environment, Food and Rural Affairs (Defra grant numbers OZ0716 and OZ0319). D. J. M. was supported by a Defra Senior Fellowship in Veterinary Microbiology. We wish to thank Drs Pauline van Diemen and Andrew Green for their assistance with the animal work.

\section{REFERENCES}

Althouse, C., Patterson, S., Fedorka-Cray, P. \& Isaacson, R. E. (2003). Type I fimbriae of Salmonella enterica serovar Typhimurium bind to enterocytes and contribute to colonization of swine in vivo. Infect Immun 71, 6446-6452.

Amavisit, P., Lightfoot, D., Browning, G. F. \& Markham, P. F. (2003). Variation between pathogenic serovars within Salmonella pathogenicity islands. J Bacteriol 185, 3624-3635.

Belden, W. J. \& Miller, S. I. (1994). Further characterization of the PhoP regulon: identification of new PhoP-activated virulence loci. Infect Immun 62, 5095-5101.

Berends, B. R., Urlings, H. A., Snijders, J. M. \& Van Knapen, F. (1996). Identification and quantification of risk factors in animal management and transport regarding Salmonella spp. in pigs. Int $J$ Food Microbiol 30, 37-53.

Bijlsma, J. J. \& Groisman, E. A. (2005). The PhoP/PhoQ system controls the intramacrophage type three secretion system of Salmonella enterica. Mol Microbiol 57, 85-96.

Bispham, J., Tripathi, B. N., Watson, P. R. \& Wallis, T. S. (2001). Salmonella pathogenicity island 2 influences both systemic salmonellosis and Salmonella-induced enteritis in calves. Infect Immun 69, 367-377.

Blanc-Potard, A. B. \& Groisman, E. A. (1997). The Salmonella selC locus contains a pathogenicity island mediating intramacrophage survival. EMBO J 16, 5376-5385.

Blanc-Potard, A. B., Solomon, F., Kayser, J. \& Groisman, E. A. (1999). The SPI-3 pathogenicity island of Salmonella enterica. J Bacteriol 181, 998-1004.

Boyen, F., Pasmans, F., Donne, E., Van Immerseel, F., Adriaensen, C., Hernalsteens, J. P., Ducatelle, R. \& Haesebrouck, F. (2006a). Role of SPI-1 in the interactions of Salmonella Typhimurium with porcine macrophages. Vet Microbiol 113, 35-44.

Boyen, F., Pasmans, F., Van Immerseel, F., Morgan, E., Adriaensen, C., Hernalsteens, J. P., Decostere, A., Ducatelle, R. \& Haesebrouck, F. (2006b). Salmonella Typhimurium SPI-1 genes promote intestinal but not tonsillar colonization in pigs. Microbes Infect 8, 2899-2907.

Clegg, S. \& Hughes, K. T. (2002). FimZ is a molecular link between sticking and swimming in Salmonella enterica serovar Typhimurium. J Bacteriol 184, 1209-1213.

Collins, D. M., Skou, B., White, S., Bassett, S., Collins, L., For, R., Hurr, K., Hotter, G. \& de Lisle, G. W. (2005). Generation of attenuated Mycobacterium bovis strains by signature-tagged mutagenesis for discovery of novel vaccine candidates. Infect Immun 73, 2379-2386.

Darwin, K. H., Robinson, L. S. \& Miller, V. L. (2001). SigE is a chaperone for the Salmonella enterica serovar Typhimurium invasion protein SigD. J Bacteriol 183, 1452-1454.

Davies, R. H., Dalziel, R., Gibbens, J. C., Wilesmith, J. W., Ryan, J. M., Evans, S. J., Byrne, C., Paiba, G. A., Pascoe, S. J. \& Teale, C. J. (2004) National survey for Salmonella in pigs, cattle and sheep at slaughter in Great Britain (1999-2000). J Appl Microbiol 96, 750-760.

Dorsey, C. W., Laarakker, M. C., Humphries, A. D., Weening, E. H. \& Baumler, A. J. (2005). Salmonella enterica serotype Typhimurium
MisL is an intestinal colonization factor that binds fibronectin. Mol Microbiol 57, 196-211.

Drecktrah, D., Knodler, L. A., Galbraith, K. \& Steele-Mortimer, O. (2005). The Salmonella SPIl effector SopB stimulates nitric oxide production long after invasion. Cell Microbiol 7, 105-113.

Dziva, F., van Diemen, P. M., Stevens, M. P., Smith, A. J. \& Wallis, T. S. (2004). Identification of Escherichia coli O157:H7 genes influencing colonization of the bovine gastrointestinal tract using signaturetagged mutagenesis. Microbiology 150, 3631-3645.

Flashner, Y., Mamroud, E., Tidhar, A., Ber, R., Aftalion, M., Gur, D., Lazar, S., Zvi, A., Bino, T. \& other authors (2004). Generation of Yersinia pestis attenuated strains by signature-tagged mutagenesis in search of novel vaccine candidates. Infect Immun 72, 908-915.

Folkesson, A., Advani, A., Sukupolvi, S., Pfeifer, J. D., Normark, S. \& Lofdahl, S. (1999). Multiple insertions of fimbrial operons correlate with the evolution of Salmonella serovars responsible for human disease. Mol Microbiol 33, 612-622.

Folkesson, A., Lofdahl, S. \& Normark, S. (2002). The Salmonella enterica subspecies I specific centisome 7 genomic island encodes novel protein families present in bacteria living in close contact with eukaryotic cells. Res Microbiol 153, 537-545.

Galan, J. E. (1996). Molecular genetic bases of Salmonella entry into host cells. Mol Microbiol 20, 263-271.

Galan, J. E. \& Curtiss, R., III (1989). Cloning and molecular characterization of genes whose products allow Salmonella typhimurium to penetrate tissue culture cells. Proc Natl Acad Sci U S A 86, 6383-6387.

Galyov, E. E., Wood, M. W., Rosqvist, R., Mullan, P. B., Watson, P. R., Hedges, S. \& Wallis, T. S. (1997). A secreted effector protein of Salmonella dublin is translocated into eukaryotic cells and mediates inflammation and fluid secretion in infected ileal mucosa. Mol Microbiol 25, 903-912.

Garcia Vescovi, E., Soncini, F. C. \& Groisman, E. A. (1996). $\mathrm{Mg}^{2+}$ as an extracellular signal: environmental regulation of Salmonella virulence. Cell 84, 165-174.

Groisman, E. A. (2001). The pleiotropic two-component regulatory system PhoP-PhoQ. J Bacteriol 183, 1835-1842.

Gunzel, D., Kucharski, L. M., Kehres, D. G., Romero, M. F. \& Maguire, M. E. (2006). The MgtC virulence factor of Salmonella enterica serovar Typhimurium activates $\mathrm{Na}^{+}, \mathrm{K}^{+}$-ATPase. J Bacteriol 188, 5586-5594.

Hensel, M. (2000). Salmonella pathogenicity island 2. Mol Microbiol 36, 1015-1023.

Hensel, M., Shea, J. E., Gleeson, C., Jones, M. D., Dalton, E. \& Holden, D. W. (1995). Simultaneous identification of bacterial virulence genes by negative selection. Science 269, 400-403.

Hong, K. H. \& Miller, V. L. (1998). Identification of a novel Salmonella invasion locus homologous to Shigella ipgDE. J Bacteriol 180, 1793-1802.

Hurd, H. S., McKean, J. D., Griffith, R. W., Wesley, I. V. \& Rostagno, M. H. (2002). Salmonella enterica infections in market swine with and without transport and holding. Appl Environ Microbiol 68, 2376-2381.

Jack, D. L., Yang, N. M. \& Saier, M. H., Jr (2001). The drug/metabolite transporter superfamily. Eur J Biochem 268, 3620-3639.

Jones, B. D. \& Falkow, S. (1994). Identification and characterization of a Salmonella typhimurium oxygen-regulated gene required for bacterial internalization. Infect Immun 62, 3745-3752.

Ku, Y. W., McDonough, S. P., Palaniappan, R. U., Chang, C. F. \& Chang, Y. F. (2005). Novel attenuated Salmonella enterica serovar Choleraesuis strains as live vaccine candidates generated by signaturetagged mutagenesis. Infect Immun 73, 8194-8203. 
Kubori, T., Sukhan, A., Aizawa, S. I. \& Galan, J. E. (2000). Molecular characterization and assembly of the needle complex of the Salmonella typhimurium type III protein secretion system. Proc Natl Acad Sci U S A 97, 10225-10230.

Leary, S. E., Williamson, E. D., Griffin, K. F., Russell, P., Eley, S. M. \& Titball, R. W. (1995). Active immunization with recombinant V antigen from Yersinia pestis protects mice against plague. Infect Immun 63, 2854-2858.

Lichtensteiger, C. A. \& Vimr, E. R. (2003). Systemic and enteric colonization of pigs by a hilA signature-tagged mutant of Salmonella choleraesuis. Microb Pathog 34, 149-154.

McClelland, M., Sanderson, K. E., Spieth, J., Clifton, S. W., Latreille, P., Courtney, L., Porwollik, S., Ali, J., Dante, M. \& other authors (2001). Complete genome sequence of Salmonella enterica serovar Typhimurium LT2. Nature 413, 852-856.

Moncrief, M. B. \& Maguire, M. E. (1998). Magnesium and the role of MgtC in growth of Salmonella typhimurium. Infect Immun $\mathbf{6 6}$, 3802-3809.

Monsieurs, P., De Keersmaecker, S., Navarre, W. W., Bader, M. W., De Smet, F., McClelland, M., Fang, F. C., De Moor, B., Vanderleyden, J. \& Marchal, K. (2005). Comparison of the PhoPQ regulon in Escherichia coli and Salmonella typhimurium. J Mol Evol 60, 462-474.

Morgan, E., Campbell, J. D., Rowe, S. C., Bispham, J., Stevens, M. P., Bowen, A. J., Barrow, P. A., Maskell, D. J. \& Wallis, T. S. (2004). Identification of host-specific colonization factors of Salmonella enterica serovar Typhimurium. Mol Microbiol 54, 994-1010.

Morgan, E., Bowen, A. J., Carnell, S. C., Wallis, T. S. \& Stevens, M. P. (2007). SiiE is secreted by the Salmonella enterica serovar Typhimurium Pathogenicity Island 4 (SPI-4)-encoded secretion system and contributes to intestinal colonization of cattle. Infect Immun 75, 1524-1533.

Norris, F. A., Wilson, M. P., Wallis, T. S., Galyov, E. E. \& Majerus, P. W. (1998). SopB, a protein required for virulence of Salmonella dublin, is an inositol phosphate phosphatase. Proc Natl Acad Sci U S A 95, 14057-14059.

Parkhill, J., Dougan, G., James, K. D., Thomson, N. R., Pickard, D., Wain, J., Churcher, C., Mungall, K. L., Bentley, S. D. \& other authors (2001). Complete genome sequence of a multiple drug resistant Salmonella enterica serovar Typhi CT18. Nature 413, 848-852.
Potter, A. A., Klashinsky, S., Li, Y., Frey, E., Townsend, H., Rogan, D., Erickson, G., Hinkley, S., Klopfenstein, T. \& other authors (2004). Decreased shedding of Escherichia coli O157 : H7 by cattle following vaccination with type III secreted proteins. Vaccine 22, 362-369.

Raetz, C. R. \& Whitfield, C. (2002). Lipopolysaccharide endotoxins. Annu Rev Biochem 71, 635-700.

Shah, D. H., Lee, M. J., Park, J. H., Lee, J. H., Eo, S. K., Kwon, J. T. \& Chae, J. S. (2005). Identification of Salmonella gallinarum virulence genes in a chicken infection model using PCR-based signature-tagged mutagenesis. Microbiology 151, 3957-3968.

Shea, J. E., Hensel, M., Gleeson, C. \& Holden, D. W. (1996). Identification of a virulence locus encoding a second type III secretion system in Salmonella typhimurium. Proc Natl Acad Sci U S A 93, 2593-2597.

Short, J. M., Fernandez, J. M., Sorge, J. A. \& Huse, W. D. (1988). Lambda ZAP: a bacteriophage lambda expression vector with in vivo excision properties. Nucleic Acids Res 16, 7583-7600.

Snavely, M. D., Miller, C. G. \& Maguire, M. E. (1991). The $m g t B \mathrm{Mg}^{2+}$ transport locus of Salmonella typhimurium encodes a P-type ATPase. J Biol Chem 266, 815-823.

Tsolis, R. M., Townsend, S. M., Miao, E. A., Miller, S. I., Ficht, T. A. Adams, L. G. \& Baumler, A. J. (1999). Identification of a putative Salmonella enterica serotype Typhimurium host range factor with homology to IpaH and YopM by signature-tagged mutagenesis. Infect Immun 67, 6385-6393.

van Diemen, P. M., Dziva, F., Stevens, M. P. \& Wallis, T. S. (2005). Identification of enterohemorrhagic Escherichia coli $\mathrm{O} 26: \mathrm{H}-$ genes required for intestinal colonization in calves. Infect Immun 73, 1735-1743.

van Velkinburgh, J. C. \& Gunn, J. S. (1999). PhoP-PhoQ-regulated loci are required for enhanced bile resistance in Salmonella spp. Infect Immun 67, 1614-1622.

Wood, M. W., Jones, M. A., Watson, P. R., Hedges, S., Wallis, T. S. \& Galyov, E. E. (1998). Identification of a pathogenicity island required for Salmonella enteropathogenicity. Mol Microbiol 29, 883-891.

Zhou, D. \& Galan, J. (2001). Salmonella entry into host cells: the work in concert of type III secreted effector proteins. Microbes Infect 3, $1293-1298$

Edited by: D. L. Gally 